$\begin{array}{ll}\text { Volume } & : 06 \\ \text { Nomor } & : 02 \\ \text { Bulan } & : \text { Mei } \\ \text { Tahun } & : 2020 \\ \text { http } & : \text { //ejurnal.pps.ung.ac.id/index.php/AKSARA/index }\end{array}$

\title{
Peningkatan Kompetensi Pedagogik Guru Kelas di SD IT Ihsanul Amal
}

\author{
Syarifuddin \\ Sekolah Tinggi Ilmu Alquran (STIQ) Amuntai Kalimantan Selatan \\ syarifuddin.stiq@gmail.com
}

Received: 23 Februari 2020; Revised: 27 April 2020; Accepted: 28 April 2020

DOI: http://dx.doi.org/10.37905/aksara.6.2.181-190.2020

\begin{abstract}
Abstrak.
Penelitian ini dilakukan di Sekolah Dasar Islam Terpadu (SD IT) Ihsanul Amal untuk mengetahui peningkatan kompetensi pedagogik guru kelas dan bagaimana kompetensi yang di miliki. Dari hasil pembahasan penulis mendapati upaya yang dilakukan untuk mengembangkan kompetensi pedagogik guru kelas adalah dengan mengikuti kegiatan pertemuan guru-guru yang diadakan oleh pihak sekolah yang diadakan setiap 3 bulan sekali oleh Kualita Pendidik Indonesia (KPI). 3 bulan pertama membahas tentang kriteria guru seperti pelatihan manajemen kelas, pembuatan RPP, pelatihan strategi mengajar, model pembelajaran, metode pembelajaran, yang terkait dengan tugas guru, mendesain kelas (Display) dan lain-lain; 3 bulan kedua meninjau kegiatan yang telah diberikan (Supervisi oleh KPI); 3 bulan ketiga menyupervisi kepala sekolah, bendahara dan; terakhir 3 bulan keempat acara seminar yang dihadiri oleh semua pihak sekolah dan orang tuan murid. Juga ada kegiatan seminar yang diadakan pihak sekolah yang dihadiri oleh orang tua anak dan seluruh pihak sekolah dilakukan per semester seperti parenting dan lain-lain. Ada juga kegiatan Forum Silaturahmi Orang tua dan Guru (FSOG) untuk menyampaikan informasi kepada orang tua peserta didik tentang perkembangan anak, diadakan setiap dua bulan sekali. Guru-guru juga diberikan keluasan untuk mengikuti kegiatan yang dapat mengembangkan kompetensi guru seperti seminar, workshop, dan lain-lain.
\end{abstract}

Kata Kunci

Peningkatan; Kompetensi Pedagogik; Guru Kelas; SD IT Ihsanul Amal

\section{PENDAHULUAN}

Sering berbagai permasalahan yang muncul dalam dunia pendidikan disebabkan oleh mutu dan kualitas pendidikan itu sendiri. Baik itu muncul dari pendidik (Guru), sistem atau pun peserta didik (siswa). Semua itu merupakan sebuah sistem fungsional yang bergandengan dan tidak bisa dipisahkan. Peserta didik (siswa) yang baik, berkualitas, kreatif, dan produktif hanya bisa dicapai dengan mutu pendidikan yang baik. Salah satu ciri dari mutu pendidikan yang baik ialah hadirnya proses pembelajaran yang baik pula (di mulai dari perencanaan, pelaksaan dan evaluasi). Guru dalam hal ini harus mampu melaksanakan perencanaan, pelaksanaan dan evaluasi dengan baik.

Guru merupakan tonggak keberhasilan dalam pembelajaran. Kualitas guru sangat menentukan jalannya kualitas pembelajaran. Guru memiliki andil besar untuk menentukan kualitas dan kuantitas pembelajaran yang hingga nanti berujung pada peningkatan taraf pendidikan Nasional. Guru berperan sebagai pengelola proses belajar-mengajar, juga bertindak sebagai fasilitator yang berusaha untuk menciptakan proses belajar-mengajar yang lebih efektif, mengembangkan bahan pelajaran dengan baik dan terus meningkatkan kemampuan peserta didik untuk menyimak pelajaran dan menguasai apa-apa yang menjadi tujuan-tujuan pendidikan yang harus mereka gapai. Bagaimanapun canggihnya teknologi sekarang, tetap tidak akan 


$\begin{array}{ll}\text { Volume } & : 06 \\ \text { Nomor } & : 02 \\ \text { Bulan } & : \text { Mei } \\ \text { Tahun } & : 2020 \\ \text { http } & : / / \text { ejurnal.pps.ung.ac.id/index.php/AKSARA/index }\end{array}$

menggantikan peran guru dalam memberikan pelajaran. Dalam proses pembelajaran guru dituntut untuk melaksanakan tugasnya dengan profesional dan sesuai fungsinya, dalam hal ini guru harus memiliki kompetensi. Selain hal tersebut, perubahan dan perkembangan masyarakat yang semakin maju juga menuntut profesi guru menyesuaikan diri dengan perubahan dan kebutuhan masyarakat. Hal yang demikian itu mengharuskan adanya perubahan di dalam mengelola kelas, mengelola lingkungan kelas, menggunakan metode mengajar, menggunakan strategi belajar-mengajar, menggunakan teknologi, maupun sikap dan karakteristik guru dalam mengelola proses belajarmengajar.

Agar dapat tercapai hal tersebut di atas, maka dengan itu, guru harus mampu memproses pembelajaran yang memberikan stimulus kepada peserta didik sehingga ia mau belajar karena memang peserta didiklah sebagai subjek utama dalam belajar. Apabila guru dapat melaksanakan hal yang disebutkan di atas maka, guru itu disebut seorang guru yang berkompetensi. Permendiknas Nomor 16 Tahun 2007 tentang Kualifikasi Akademik dan Kompetensi Guru, Standar kompetensi guru ini dikembangkan secara utuh dari empat kompetensi utama, yaitu kompetensi pedagogik, kepribadian, sosial, dan profesional.

Peningkatan dan pengembangan kualitas kompetensi guru selama ini diserahkan kepada masing-masing guru yang bersangkutan. Jika guru itu hendak mengembangkan dirinya sendiri, maka guru itu akan bermutu dan berkualitas, karena selalu mencari peluang untuk meningkatkan mutu dan kualitasnya sendiri.

Peningkatan kompetensi pedagogik yang dimaksudkan dalam penelitian ini adalah yang tertuang menurut Standar Nasional Pendidikan, pada Pasal 28 ayat (3) butir a dikemukakan bahwa kompetensi pedagogik adalah kemampuan mengelola pembelajaran peserta didik yang meliputi 1) pemahaman terhadap peserta didik; 2) perancangan pembelajaran; 3) pelaksanaan pembelajaran; 4) evaluasi hasil belajar dan; 5) pengembangan peserta didik untuk mengaktualisasikan berbagai jenis potensi yang dimilikinya. Dalam hal ini guru di sekolah sudah memiliki beberapa kompetensi Pedagogik dan harus ditingkatkan lagi, agar tujuan pendidikan bisa tercapai dengan efektif dan efisien. Pentingnya upaya untuk meningkatkan kompetensi pedagogik agar mutu dan kualitas pembelajaran disekolah dapat meningkat, maka dengan itu penelitian ini fokus kepada peningkatan kompetensi pedagogik guru diSekolah Dasar Islam Terpadu (SD IT) Ihsanul Amal.

\section{KAJIAN PUSAKA}

\section{Pengertian kompetensi}

Pengertian dasar kompetensi (competency) adalah kemampuan atau kecakapan (Rofa'ah, 2016, p. 30). Menurut KBBI kompetensi adalah kewenangan (kekuasaan) untuk menentukan (memutuskan) sesuatu (Tim Penyusun, Sugono, Sugiyono, Maryani, \& Taqdir Qodratillah, 2008, p. 743). Kompetensi menurut Webster's Dictionary mulai muncul pada tahun 1596. Istilah ini diambil dari kata latin "competere" yang artinya "to be suitable". Kemudian ini secara substansial mengalami perubahan dengan masuknya berbagai isu dan pembahasan mengenai konsep kompetensi dari berbagai literature (Pianda, 2018, p. hal.30). Kompetensi berasal dari bahasa Inggris yaitu competence. Maknanya sama dengan being competent, sedangkan competent sama artinya dengan having ability, power, authoority, skill, knowledge, attitude. Dengan demikian kompetensi adalah kemampuan, kecakapan, keterampilan dan pengetahuan seseorang dibidang tertentu (muh., n.d., p. 53).

Dalam Alquran surah Al-Ankabut ayat 7 firman-Nya

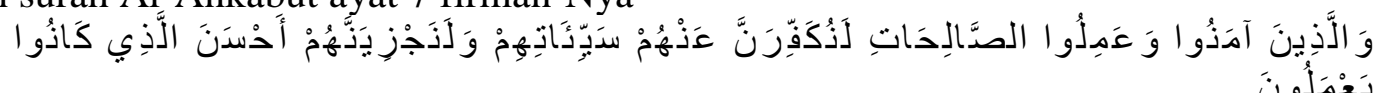




$\begin{array}{ll}\text { Volume } & : 06 \\ \text { Nomor } & : 02 \\ \text { Bulan } & : \text { Mei } \\ \text { Tahun } & : 2020 \\ \text { http } & : / / \text { ejurnal.pps.ung.ac.id/index.php/AKSARA/index }\end{array}$

Artinya: "Dan orang-orang yang beriman dan beramal saleh, benar-benar akan Kami hapuskan dari mereka dosa-dosa mereka dan benar-benar akan Kami beri mereka balasan yang lebih baik dari apa yang mereka kerjakan".

Undang-undang RI No. 14 tahun 2005 mengartikan kompetensi guru adalah sebagai berikut "seperangkat pengetahuan, keterampilan dan perilaku yang harus dimiliki, dihayati, dan dikuasai oleh guru atau dosen dalam melaksanakan tugas profesional". Dalam penjelasan ini bahwa kompetensi memang diarahkan agar bisa digunakan secara praktis di dalam kehidupan sehari-hari, terutama dalam suatu profesi pekerjaan ataupun di bidang lainnya.

Berdasarkan uraian di atas, dapat disimpulkan bahwa kompetensi adalah kemampuan atau kecakapan, keterampilan, pengetahuan, kewenangan (kekuasaan) untuk memutuskan sesuatu dalam bidang tertentu.

Kompetensi guru berarti kemampuan yang harus dimiliki oleh seorang guru. Dalam penelitian ini peneliti menjabarkan perbedaan guru kelas dan guru mata pelajaran. Guru kelas adalah guru yang mengatur absensi mengampu dan mengajar semua mata pelajaran kecuali mata pelajaran Agama dan Olahraga. Sebagaimana yang ditulis oleh Melly handayani (Mellyhandayani, 2015) mengatakan bahwa "Guru kelas adalah guru yang mengikuti kelas pada satuan pendidikan sekolah dasar atau yang sederajat, yang bertugas melaksanakan pembelajaran seluruh mata pelajaran pada satuan pendidikan tersebut, kecuali pendidikan agama dan olahraga".

\section{Kompetensi Guru}

Kompetensi merupakan seperangkat pengetahuan keterampilan dan perilaku tugas yang harus dimiliki. Setelah dimiliki, tentu harus dihayati, dikuasai, dan diwujudkan oleh guru dalam melaksanakan tugas keprofesionalan di dalam kelas yang disebut sebagai pengajaran. Kompetensi guru meliputi kompetensi pedagogik, kompetensi kepribadian, kompetensi sosial, dan kompetensi profesional sebagai tuntutan dari profesi (Sembiring, n.d., pp. 39-40).

a. Kompetensi Pedagogik

Kompetensi Pedagogik Merupakan kemampuan guru dalam pengelolaan pembelajaran untuk keperluan peserta didik. Sekurang-kurangnya meliputi pemahaman atau wawasan terhadap peserta didik landasan kepemimpinan. Selain itu juga meliputi kemampuan dalam pengembangan kurikulum, silabus, RPP, dan termasuk juga perancangan dalam pelaksanaan pembelajaran yang mendidik serta dialogis. Juga memanfaatkan teknologi di dalam pembelajaran, evaluasi akhir belajar, dan mengembangkan potensi peserta didik. Ini semua dimaksudkan demi mengaktualisasikan berbagai potensi yang dimiliki oleh guru, sekali lagi untuk kepentingan pencapaian tujuan pembelajaran dan tujuan pendidikan.

b. Kompetensi Kepribadian

Kompetensi Kepribadian mencakup perilaku yang mantap, stabil, dewasa, arif, bijaksana, berwibawa berakhlak mulia, serta menjadi teladan bagi peserta didik dan masyarakat. Secara objektif harus mampu mengevaluasi kinerja sendiri dan mengembangkan diri secara mandiri untuk terus menjadi pribadi yang lebih baik.

c. kompetensi sosial

kompetensi Sosial adalah kemampuan guru sebagai anggota dari masyarakat yang sekurang-kurangnya memiliki kompetensi berkomunikasi lisan, berkomunikasi tulisan, dan/atau berkomunikasi secara isyarat.

d. Kompetensi Profesional

Kompetensi Profesional merupakan wujud nyata kemampuan dalam menguasai materi pelajaran secara mendalam.

Empat kompetensi di atas dapat diringkas sebagai berikut: kompetensi pedagogik adalah kompetensi mengelola pembelajaran peserta didik (Surakhmad, 2009, p. 304). Seorang guru harus 


$\begin{array}{ll}\text { Volume } & : 06 \\ \text { Nomor } & : 02 \\ \text { Bulan } & : \text { Mei } \\ \text { Tahun } & : 2020 \\ \text { http } & : / / \text { ejurnal.pps.ung.ac.id/index.php/AKSARA/index }\end{array}$

mampu mengelola pembelajaran. Berikutnya kompetensi kepribadian seperti: berjiwa mantap, berakhlak mulia, arif, berwibawa, menjadi teladan bagi peserta didik (Surakhmad, 2009, p. 304). Berikutnya kompetensi profesional adalah penguasaan materi pelajaran secara luas dan mendalam (Surakhmad, 2009, p. 304). Berikutnya kompetensi sosial adalah mampu berkomunikasi dan berinteraksi dengan manusia sekitarnya.

\section{Pengertian Pedagogik}

Pedagogik mengandung pengertian ilmu pendidikan (Rifma, 2016, p. 9). oleh Saudagar dan Idrus (2009:33) mengemukakan bahwa pedagogik adalah ilmu tentang pendidikan anak yang ruang lingkupnya terbatas pada interaksi edukasi antar pendidik dengan peserta didik. Sedangkan kompetensi pedagogik adalah kemampuan seorang guru dalam mengelola proses pembelajaran peserta didik (Fatah Yasin, 2012, pp. 163-165). Dapat ditarik kesimpulan berdasarkan pengertian di atas bahwa yang dimaksud dengan pedagogik adalah ilmu yang berkaitan dengan pendidikan anak dengan ruang lingkupnya terbatas pada interaksi edukatif antar guru bersama peserta didik.

Pengertian kompetensi pedagogik dalam Standar Nasional Pendidikan pasal 28 ayat (3) butir a adalah sebagai berikut (Mulyasa, 2013, p. 75): "kemampuan mengelola pembelajaran peserta didik yang meliputi pemahaman terhadap peserta didik, perancangan dan pelaksanaan pembelajaran, evaluasi hasil belajar dan pengembangan peserta didik untuk mengaktualisasikan berbagai jenis potensi yang dimilikinya. Maka dari pengertian di atas bahwa bisa diambil kesimpulan bahwa kompetensi pedagogik meliputi: a) pemahaman terhadap peserta didik; b) perancangan pembelajaran; c) pelaksanaan pembelajaran; d) evaluasi hasil belajar; dan e) pengembangan peserta didik untuk mengaktualisasikan berbagai jenis potensi yang dimilikinya.

Kompetensi pedagogik ialah kemampuan pendidik dalam mengelola pembelajaran harus memiliki kemampuan mengelola peserta didiknya meliputi: a) kemampuan dalam memahami peserta didik, dengan indikator sebagai berikut: 1) mengerti karakteristik perkembangan siswa, seperti mempertimbangkan dan memahami tingkatan usia siswa, 2) mengerti asas-asa pertumbuhan kepribadian siswa, sebagaimana mengetahui tipe-tipe kepribadian siswa, mengidentifikasi jenjang perkembangan kepribadian siswa dan sebagainya, 3) dapat mengenali persiapan saja awal siswa, sebagaimana menilai potensi awal siswa, mengidentifikasi perbedaan kemampuan yang dipunyai siswa, dan sebagainya; b) kemampuan dalam membuat perancangan pembelajaran, dengan indikator sebagai berikut: 1) dapat mengatur penyusunan bahan pembelajaran, semacam dapat mengulas dan menguraikan bahan materi yang termuat di dalam kurikulum, dapat memilah bahan ajar yang sinkron dengan materi, dapat menggunakan berbagai pangkal belajar yang sesuai dengan materi, dan sebagainya, 2) mampu merencanakan pengelolaan pembelajaran, sebagaimana dapat mengartikan tujuan pembelajaran searah dengan kompetensi yang akan dicapai, menentukan jenis strategi/metode pembelajaran yang sesuai, menetapkan tahapan-tahapan pembelajaran, menetapkan langkah yang dipakai untuk memberi motivasi siswa, menetapkan ragam soalan yang akan dilontarkan kepada siswa, dan sebagainya, 3) dapat melaksanakan pengorganisasian kelas, sebagaimana mengatur ruang tempat duduk siswa, membagi-bagikan waktu belajar, dan sebagainya, 4) dapat menyusun aplikasi media dan sarana yang dapat dipakai untuk mempermudah tercapainya kompetensi, dan sebagainya, 5) dapat menyusun model penilaian proses pembelajaran, sebagaimana menentukan bentuk, prosedur, dan alat penilaian; c) kemampuan melaksanakan pembelajaran, dengan indikator sebagai berikut: 1) dapat mengaplikasikan kemahiran dasar mengajar, sebagaimana membuka pelajaran, menerangkan pelajaran, pola variasi, memberi pertanyaan, menambah penguatan dan mengakhiri/menutup pelajaran, 2) dapat mengaplikasikan beraneka ragam jenis pendekatan, strategi, metode pembelajaran, seperti metode konvensional/ceramah, metode diskusi, metode demonstrasi, metode resitasi, metode percobaan, metode karya wisata, metode pemecahan 


$\begin{array}{ll}\text { Volume } & : 06 \\ \text { Nomor } & : 02 \\ \text { Bulan } & : \text { Mei } \\ \text { Tahun } & : 2020 \\ \text { http } & : / / \text { ejurnal.pps.ung.ac.id/index.php/AKSARA/index }\end{array}$

masalah, aktif learning, pembelajaran portofolio, CTL, pembelajaran kontekstual dan sebagainya, 3) dapat mengelola kelas, sebagaimana membangkitkan semangat siswa untuk bertanya, dapat memenuhi keinginan tahuan siswa dan memandu pertanyaan siswa, kerja kelompok, kerja mandiri, dan sebagainya, 4) dapat menakar tingkat ketercapaian kompetensi siswa ketika proses pembelajaran sedang berlangsung; d) kemampuan dalam mengevaluasi hasil belajar (Fatah Yasin, 2012, pp. 163-165).

\section{Landasan Hukum Kompetensi Pedagogik}

Landasan hukum menjelaskan bahwa Kompetensi pedagogik yang sesuai dengan UU RI Guru dan Dosen Nomor 14 tahun 2005 dan PP Nomor 19 tahun 2005 adalah merupakan kemampuan yang berkaitan dengan pemahaman peserta didik dan mengelola pembelajaran yang mendidik dan dialogis. Tim Direktorat Profesi Pendidikan Ditjen Peningkatan Mutu Pendidikan dan Tenaga Kependidikan (2006) telah merumuskan secara subtantif kompetensi pedagogik yang meliputi kemampuan terhadap peserta didik; Pemahaman wawasan atau landasan kependidikan; pengembangan peserta didik untuk mengaktualisasikan berbagai potensi yang dimilikinya.

Undang-undang Sistem Pendidikan Nasional (SISDIKNAS) Nomor 20 Tahun 2003, pasal 1 ayat 1 berisikan pengertian pendidikan adalah "usaha sadar dan terencana untuk mewujudkan suasana belajar dan proses pembelajaran agar peserta didik secara aktif mengembangkan potensi dirinya untuk memiliki kekuatan spiritual keagamaan, pengendalian diri, kepribadian, kecerdasan akhlak mulia serta keterampilan yang diperlukan dirinya, masyarakat, bangsa dan negara”. Oleh sebab itu maka pendidikan adalah memproses warga negara menjadi insan yang bertaqwa, berakhlak, cerdas dan terampil. Adapun untuk mencapai hal tersebut maka diselenggarakanlah kegiatan pembelajaran yang bersifat formal, non formal, maupun informal dengan berbagai jenjang mulai dari pendidikan usia dini hingga pendidikan tinggi.

Bisa kita ambil kesimpulan dari penjelasan di atas bahwa kompetensi pedagogik itu adalah kemampuan pemahaman terhadap peserta didik secara mendalam dan penyelenggaraan pembelajaran yang mendidik pemahaman tentang peserta didik meliputi kemampuan merancang pembelajaran, mengimplementasikan pembelajaran, menilai proses hasil pembelajaran, dan melakukan perbaikan secara berkelanjutan (Nurhamidah, 2018, p. 32).

\section{METODE PENELITIAN}

Pada penelitian ini menggunakan pendekatan kualitatif. Pendekatan yang digunakan dalam penelitian ini adalah studi kasus agar penelaahan terhadap fokus penelitian bisa dijalankan secara intensif, mendalam, detail, dan komprehensif.

Penelitian ini mengambil lokasi di Sekolah Dasar Islam Terpadu (SD IT) Ihsanul Amal Amuntai. Ada beberapa alasan dipilihnya lokasi tersebut yang antaranya adalah sebagai berikut: 1) Sekolah Dasar Swasta ini sering di datangi oleh berbagai pihak sekolah yang setingkat untuk menjadi acuan/studi banding dari sekolahan swasta lainnya. 2) Sekolah ini berada sekitar $6 \mathrm{~km}$ dari pusat kota Amuntai. 3) Sekolah Dasar ini, para peserta didiknya sering ikut dan mewakili berbagai lomba, baik tingkat daerah maupun tingkat Nasional. 4) Sekolah Dasar ini memiliki berbagai keunggulan yang dibuktikan dengan adanya berbagai prestasi yang pernah diraih, baik prestasi akademik maupun non akademik. 5) Sekolah Dasar ini telah mempunyai tenaga pendidik dan fasilitas saran dan prasarana yang cukup memadai. 6) rata-rata yang masuk ke sekolah ini adalah dari kalangan mayoritas ekonomi menengah ke atas, ini menjadi keunikan tersendiri bahwa ternyata walau jauh dari kota orang-orang yang kelas atas tidak ragu-ragu menyekolahkan anakanak mereka. Padalah di kota sendiri masih banyak sekolah-sekolah lebih maju dan unggul yang sudah lama berdiri. 


$\begin{array}{ll}\text { Volume } & : 06 \\ \text { Nomor } & : 02 \\ \text { Bulan } & : \text { Mei } \\ \text { Tahun } & : 2020 \\ \text { http } & : / / \text { ejurnal.pps.ung.ac.id/index.php/AKSARA/index }\end{array}$

Dalam teknik pengumpulan data penelitian kualitatif, secara garis besarnya dapat dibedakan menjadi dua kategori: teknik yang bersifat interaktif melalui wawancara serta pengamatan (observasi) dan teknik yang sifatnya non interaktif dengan cara dokumentasi (Yusuf, 2016, pp. 372-391). Maka cara pengumpulan data diperoleh dengan tiga teknik, ialah 1) wawancara mendalam (in depth interview); 2) pengamatan (observasi); dan 3) dokumentasi.

Metode yang digunakan dalam penelitian ini adalah studi kasus yaitu bertujuan secara khusus untuk menjelaskan dan memahami objek yang diteliti secara khusus sebagai suatu kasus (Luthfiyah \& Fitrah, 2018, p. 209). Maka dalam hai ini yang menjadi objek penelitiannya adalah guru kelas. Penelitian ini juga menjadi jembatan untuk mengungkapkan kekhasan atau keunikan karakteristik yang dimiliki oleh guru kelas.

Instrumen utama (Bungin, n.d., p. 137) penelitian ini adalah peneliti dengan menggunakan alat bantu recorder, kamera, pedoman wawancara, dan alat-alat lain yang diperlukan secara insidental. Lofland menuturkan bahwa ada beberapa sumber utama dalam penelitian kualitatif seperti kata-kata, dan tindakan, selain dari yang disebutkan adalah data tambahan contohnya dokumen dan lainya. yang dimaksud sumber data dalam penelitian adalah subjek dari mana datadata didapatkan atau diperoleh. Populasi dalam kualitatif disebut dengan social situation (situasi sosial) yang dibagi atas tiga elemen: place (tempat), actor (pelaku) dan activity (aktivitas) yang berinteraksi secara sinergi (Sugiyono, 2011, p. 215). Adapun dalam pemilihan informan peneliti menggunakan tehnik purposive yaitu memilih orang yang dipandang tahu dan menguasai tentang bagaimana situasi sosial yang diteliti. Informannya adalah kepala sekolah, waka kurikulum, guru dan peserta didik.

\section{HASIL DAN PEMBAHASAN}

Perspektif historis menunjukkan bahwa Sejarah singkat berdirinya Sekolah Dasar Islam Terpadu (SD IT) Ihsanul Amal. Sekolah selalu dituntut untuk mengikuti perkembangan zaman, pada masa yang akan datang akan hadir persaingan yang sangat ketat, perubahan- perubahan yang sangat cepat, berbagai macam tantangan, hingga kebutuhan kepada kehidupan beragama yang lebih mengedepankan akhlak serta hadirnya eksis krisis keadaan sosial dan lingkungan masyarakat. Agar dapat memenuhi tantangan-tantangan yang hadir dimasa yang akan datang dari itulah yayasan Ihsanul Amal terbentuk dan mendedikasikan dirinya untuk ummat ini di dalam dunia pendidikan (Amirudin, 2016).

Kata Ihsanul Amal diambil dari bahasa arab dari kata "Ahsana" dan "amala". Ihsanul Amal yang berarti perbuatan terbaik. Dari makna kata itulah gagasan tercipta. Alquran surah Al-Mulk: 2 firman Allah SWT.

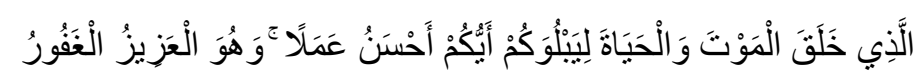

Artinya: Yang menjadikan mati dan hidup, supaya Dia menguji kamu, siapa di antara kamu yang lebih baik amalnya. Dan Dia Maha Perkasa lagi Maha Pengampun

Kata ahsana dan amala yang bermakna perbuatan baik, maka harapannya adalah semoga di sekolah dasar Ihasnul Amal ini akan lahir manusia-manusia terbaik, beramal dengan amal-amal yang baik, agar nantinya menjadi ummat yang terbaik dan nantinya semoga suatu saat nanti Allah kumpulkan dengan kelompok-kelompok orang-orang yang terbaik, aamiin (Amirudin, 2016).

Sekolah Dasar Islam Terpadu (SDIT) Ihsanul Amal Merupakan salah satu dari bagian sekolah dasar Islam di Indonesia yang terhimpun di dalam Jaringan Sekolah Islam Terpadu (JSIT) yang ada di Indonesia.

Pada tahun 2008 adalah awal didirikannya SDIT Ihsanul Amal. Awalnya tempat yang dijadikan sebagai kegiatan belajar adalah rumah Bimbingan Belajar (BimBel) milik almarhum Pak Huri dengan status sewa/kontrak yang berlamatkan di Alamatan. Setelah setengah tahun berjalan 


$\begin{array}{ll}\text { Volume } & : 06 \\ \text { Nomor } & : 02 \\ \text { Bulan } & : \text { Mei } \\ \text { Tahun } & : 2020 \\ \text { http } & : / / \text { ejurnal.pps.ung.ac.id/index.php/AKSARA/index }\end{array}$

maka, SDIT Ihsanul Amal pindah di dekat rumah Muallim KH. A. Mu'thi yang beralamatkan di komplek perumahan Citra Permai Indah (CPI) dengan status sewa/kontrak juga. Hingga pada tahun 2009 SDIT Ihsanul Amal sempat menyewa ruko dekat dengan kios kue bolu H. Enong yang beralamatkan di desa Palampitan Hilir. Sampai pada akhirnya ada seorang yang dermawan menghibahkan tanah agar bisa dikelola dan dijadikan tempat pendidikan hingga sampai sekarang (Baderi, 2016). Dengan demikian, Sekolah Dasar Islam Terpadu (SD IT) Ihsanul Amal telah memiliki wadah agar bisa melangsungkan pembelajaran dan pendidikan.

Semua hal ini dapat disaksikan pada keuletan dan ketekunan guru-gurunya di dalam melaksanakan tugas dan kewajiban sebagai pendidik, dengan penuh kesadaran, tanggung jawab dan kedisiplinan serta kasih sayang terhadap peserta didiknya. Di tunjang dengan sekolah yang bernafaskan Islami dengan menerapkan asas persaudaraan dan kekeluargaan. Dapat disaksikan ketika guru-gurunya beserta staf-stafnya saat bertemu di sekolah dan berpisah tidak pernah lupa untuk memberi salam dan berjabat tangan (laki-laki berjabat tangan dengan laki-laki, begitu juga perempuan berjabat tangan dengan perempuan) (Syarifuddin, 2016).

Keharmonisan antara guru dan peserta didik juga bisa disaksikan pada perilaku peserta didik kepada guru-gurunya pada saat setiap kali berjumpa dan berpisah senantiasa berjabat tangan dan memberikan salam. Sebaliknya pula perlakuan guru terhadap peserta didiknya sangat ramah dan dengan penuh rasa cinta kasih sayang (Syarifuddin, 2016). Hingga dengan seperti itu, bahwa sekolah telah mampu membina sikap mental dan moral yang tinggi kepada peserta didiknya yang dibentuk sejak dini.

Sekolah Dasar Islam Terpadu (SD IT) Ihsanul Amal memiliki Memiliki visi: "Terwujudnya generasi yang sholeh, mandiri dan berbudaya lingkungan". Adapun misinya adalah: 1) mendidik secara islami agar menjadi generasi yang sholeh; 2) melaksanakan pembelajaran yang mudah, menyenangkan dan menyentuh hati untuk menumbuhkan kecerdasan siswa-siswi; 3) membimbing siswa-siswi meningkatkan keterampilan hidup agar mampu beradaptasi dengan lingkungan; 4) menumbuhkan rasa peduli terhadap upaya pelestarian, pencegahan, pencemaran dan kerusakan lingkungan ('Dokumentasi SD IT Ihsanul Amal', 2016).

Sekolah Dasar Islam Terpadu (SD IT) Ihsanul Amal memiliki Motto:('SDIT Ihsanul Amal', n.d.) 1) Ceria: melaksanakan pembelajaran yang mudah, menyenangkan dan menyentuh hati; 2) kreatif: meningkatkan keterampilan hidup agar mampu beradaptasi terhadap lingkungan; 3) sehat: menumbuhkan rasa peduli terhadap upaya pelestarian lingkungan; 4) sholeh: mengenal Allah dan Rasu-Nya, terbiasa sholat waktu berjamaah; 5) mandiri: disiplin dan tanggung jawab; 6) berbudaya lingkungan: menciptakan lingkungan yang bersih, sehat dan menyenangkan.

\section{Kompetensi Pedagogik Guru Kelas dalam Memahami Peserta Didik.}

Subkompetensi ini memiliki indikator esensial: memahami peserta didik dengan memanfaatkan prinsip-prinsip perkembangan kognitif, memahami peserta didik dengan memanfaatkan prinsip-prinsip kepribadian; dan mengidentifikasi bekal-ajar awal peserta didik.

Adapun beberapa indikator yang harus dipenuhi guru kelas untuk memahami peserta didik adalah sebagai berikut:

a. Memahami tingkat kecerdasan peserta didik

Dalam memahami tingkat kecerdasan peserta didik guru kelas melihat dari hasil evaluasi dan dari kecakapan di dalam kelas melalui 3 aspek seperti unsur kognitif, afektif, dan psikomotorik.

b. Memahami tingkat kreativitas peserta didik

Dalam hal memahami tingkat kreativitas peserta didik guru kelas melihatnya dari hasil oleh bakat kreativitas anak dan dalam kegiatan outdoor (pembelajaran di luar kelas).

c. Memahami tentang kelainan fisik peserta didik 


$\begin{array}{ll}\text { Volume } & : 06 \\ \text { Nomor } & : 02 \\ \text { Bulan } & : \text { Mei } \\ \text { Tahun } & : 2020 \\ \text { http } & : / / \text { ejurnal.pps.ung.ac.id/index.php/AKSARA/index }\end{array}$

Dalam hal ini guru kelas memahami kelainan fisik peserta didik tidak memandang fisik selama peserta didik mampu mengikuti pelajaran maka tidaklah dibedakan antara peserta didiknya. d. Memahami perkembangan peserta didik

Dalam hal ini guru kelas memahami perkembangan peserta didik dengan melihat usia peserta didiknya, melihat berbagai tipe kepribadian peserta didik, dan melihat bagaimana karakter setiap peserta didiknya.

\section{Kompetensi Guru Kelas dalam Merancang Pembelajaran.}

Dalam hal ini guru kelas merancang pembelajaran berdasarkan Atwi Suparman dalam Andi Prastowo(Prastowo, 2017, pp. 152-153) mengurutkan bahwa yang harus diakukan guru kelas yaitu: 1) guru perlu menguasai bahan pembelajaran dengan baik atau sangat baik; 2) guru perlu terampil merancang dan melaksanakan strategi pembelajaran, di dalamnya meliputi tahapan dan langkah-langkah pembelajaran yang runtun pada saat menyajikan isi pembelajaran, menggunakan berbagai metode, media, dan alat, mengelola waktu yang telah dialokasikan dengan efisien, dan melakukan upaya-upaya motivasi penguatan dan penghargaan (reward) sepanjang proses pembelajaran; 3) guru perlu mampu menggunakan sumber belajar di perpustakaan, peralatan yang tersedia di laboratorium, di ruang pembelajaran, dan/atau mampu menciptakan sendiri sumbersumber belajar lain bila sumber belajar yang ideal tidak tersedia; 4) guru mampu merancang dan menggunakan alat pengukur yang baik dan sesuai dengan kompetensi dalam tujuan pembelajaran; 5) guru mampu memperoleh dukungan dari tenaga kependidikan dan pengelola satuan pendidikan di tempatnya bekerja.

Persiapan sebelum masuk kelas, di rumah sudah mulai membaca-baca buku untuk pelajaran hari esok. Materinya ini dan bahan medianya apa yang diperlukan sudah disiapkan, yang semuanya tertuang di dalam RPP.

\section{Kompetensi Guru Kelas dalam Melaksanakan Pembelajaran.}

Sri Yutmini (Yutmini, 1992, p. 13) menyebutkan bahwa ada beberapa persyaratan kemampuan yang harus di miliki oleh seorang guru dalam melaksanakan proses belajar-mengajar, kemampuan belajar-mengajar meliputi: a) menggunakan metode mengajar, media pelajaran, dan bahan latihan yang disesuaikan dengan apa yang menjadi tujuan pelajaran; b) mendemonstrasikan penguasaan mata pelajaran dan perlengkapan pengajaran; c) memiliki komunikasi yang baik dengan peserta didik; d) mendemonstrasikan berbagai metode mengajar; dan e) melaksanakan evaluasi proses belajar-mengajar. Dalam pelaksanaannya guru kelas memberikan pengetahuan teori belajar-mengajar kepada peserta didiknya. Pembelajaran tidak hanya dilakukan di dalam kelas akan tetapi juga dilakukan di luar kelas seperti: halaman, perpustakaan, dan terkadang di luar dari kawasan sekolah.

Guru kelas menggunakan sarana dan prasarana yang telah disediakan oleh pihak sekolah dan juga peserta didik dan pendidik dalam kesempatan berkarya mampu membuat bahan ajar dengan bahan yang sederhana bahkan dari barang daur ulang.

Guru kelas sudah mampu melaksanakan proses pembelajaran seperti diterapkannya keterampilan dasar dalam mengajar: membuka pelajaran, menjelaskan isi materi, menggunakan metode yang bervariasi, bertanya kepada peserta didik, memberi penguat atas jawaban peserta didik dan menutup pembelajaran.

\section{Kompetensi Guru Kelas dalam Evaluasi Hasil Belajar}

Evaluasi dapat diartikan sebagai usaha untuk mengklasifikasikan siswa sesuai dengan kriteria kualitas tertentu (Basuki \& Hariyanto, M.S, 2015, p. 222). Adapun maksud dari evaluasi adalah suatu proses penafsiran terhadap kemajuan, pertumbuhan dan perkembangan anak didik untuk tujuan pendidikan (Muhaimin \& Mujib, 1993, pp. 276-277).

Maka teknik penilaian harus disesuaikan dengan hal-hal sebagai berikut: a) kompetensi yang diukur; b) aspek yang diukur (pengetahuan, keterampilan, atau sikap); c) kemampuan siswa 


$\begin{array}{ll}\text { Volume } & : 06 \\ \text { Nomor } & : 02 \\ \text { Bulan } & : \text { Mei } \\ \text { Tahun } & : 2020 \\ \text { http } & : / / \text { ejurnal.pps.ung.ac.id/index.php/AKSARA/index }\end{array}$

yang diukur; d) sarana dan prasarana yang ada (Rukajat, 2018, p. 40). Dalam hal ini guru kelas menilai kemampuan peserta didik dengan aspek pengetahuan dengan diadakannya tes tertulis dan tidak tertulis. Keterampilan atau sikap dilakukan dengan melihat perkembangan perilaku peserta didik yang diamati melalui buku pengamatan perkembangan peserta didik (disediakan oleh sekolah). Guru kelas melakukan remedial bagi peserta didik yang nilainya tidak mencapai standar KKM.

\section{Kompetensi Guru Kelas dalam Mengembangkan Peserta Didik untuk Mengaktualisasikan Berbagai Potensi yang Dimilikinya.}

Dalam hal ini guru kelas mengembangkan peserta didik untuk mengaktualisasikan berbagai potensi peserta didik yaitu dengan memberikan fasilitas seluas-luasnya kepada peserta didik. Sekolah dalam hal ini sangat mensupport setiap guru yang menemukan bakat-bakat tertentu dari peserta didik dengan memberikan fasilitas yang diperlukan.

Dari hasil pembahasan penulis mendapati upaya yang dilakukan untuk mengembangkan kompetensi pedagogik guru kelas adalah dengan mengikuti kegiatan pertemuan guru-guru yang diadakan oleh pihak sekolah yang diadakan setiap 3 bulan sekali oleh Kualita Pendidik Indonesia (KPI). 3 bulan pertama membahas tentang kriteria guru seperti pelatihan manajemen kelas, pembuatan RPP, pelatihan strategi mengajar, model pembelajaran, metode pembelajaran, yang terkait dengan tugas guru, mendesain kelas (Display) dan lain-lain; 3 bulan kedua meninjau kegiatan yang telah diberikan (Supervisi oleh KPI); 3 bulan ketiga menyupervisi kepala sekolah, bendahara dan; terakhir 3 bulan keempat acara seminar yang dihadiri oleh semua pihak sekolah dan orang tuan murid. Juga ada kegiatan seminar yang diadakan pihak sekolah yang dihadiri oleh orang tua anak dan seluruh pihak sekolah dilakukan per semester seperti parenting dan lain-lain. Ada juga kegiatan Forum Silaturahmi Orang tua dan Guru (FSOG) untuk menyampaikan informasi kepada orang tua peserta didik tentang perkembangan anak, diadakan setiap dua bulan sekali. Guru-guru juga diberikan keluasan untuk mengikuti kegiatan yang dapat mengembangkan kompetensi guru seperti seminar, workshop, dan lain-lain.

\section{SIMPULAN}

Penelitian menjelaskan bahwa Kompetensi pedagogik yang dilakukan oleh guru kelas di SD IT Ihsanul Amal sudah baik karena selalu disupervisi oleh pihak sekolah. Baik itu kepala sekolah, waka kurikulum, ataupun orang yang ditunjuk untuk memberikan supervisi terhadap guru kelas. Kompetensi Pedagogik bertugas untuk mempelajari fenomena pendidikan untuk sampai membangun suatu pengetahuan sistematis sehingga diperoleh pemahaman yang jelas mengenai objek studinya tersebut. Kompetensi pedagogik juga bertugas untuk membangun sistem pengetahuan mengenai bagaimana seharusnya pendidik bertindak dalam rangka mendidik anak.

\section{DAFTAR PUSTAKA}

Amirudin. (2016). Wawancara SD IT Ihsanul Amal.

Baderi, M. (2016). Wawancara SD IT Ihsanul Amal.

Basuki, I., \& Hariyanto, M.S. (2015). Asesmen Pembelajaran. Jakarta: PT Remaja Rosdakarya. Bungin, B. (n.d.). Metodologi Penelitian Kuantitatif. Kencana.

Dokumentasi SD IT Ihsanul Amal. (2016, November 10).

Fatah Yasin, A. (2012). PENGEMBANGAN KOMPETENSI PEDAGOGIK GURU PENDIDIKAN AGAMA ISLAM DI MADRASAH (Studi Kasus di MIN Malang I). ElQUDWAH, 0(0). Retrieved 11 May 2019 from http://ejournal.uinmalang.ac.id/index.php/lemlit/article/view/1942

Kompetensi Pedagogik Guru Indonesia «Mahmuddin. (n.d.). Retrieved 7 May 2019, from https://mahmuddin.wordpress.com/2008/03/19/kompetensi-pedagogik-guru-indonesia/ 


$\begin{array}{ll}\text { Volume } & : 06 \\ \text { Nomor } & : 02 \\ \text { Bulan } & : \text { Mei } \\ \text { Tahun } & : 2020 \\ \text { http } & : / / \text { ejurnal.pps.ung.ac.id/index.php/AKSARA/index }\end{array}$

Luthfiyah, \& Fitrah, M. (2018). Metodologi penelitian: penelitian kualitatif, tindakan kelas \& studi kasus. CV Jejak Publisher.

Mellyhandayani. (2015, May 16). PERAN DAN TANGGUNG JAWAB GURU KELAS, GURU BIDANG STUDI DAN GURU PEMBIMBING KHUSUS DAN KERJASAMA DENGAN ORANG TUA DAN MASAYARAKAT DALAM PENDIDIKAN INKLUSIF. $\begin{array}{lllll}\text { Retrieved } & 7 & \text { May } & 2019 & \text { from }\end{array}$ https://mellyhandayanicyrus.wordpress.com/2015/05/16/peran-dan-tanggung-jawabguru-kelas-guru-bidang-studi-dan-guru-pembimbing-khusus-dan-kerjasama-denganorang-tua-dan-masayarakat-dalam-pendidikan-inklusif/

muh., I. I. (n.d.). KINERJA DAN KOMPETENSI GURU DALAM PEMBELAJARAN | Ismail | Lentera Pendidikan: Jurnal Ilmu Tarbiyah dan Keguruan. Retrieved 6 May 2019, from http://journal.uin-alauddin.ac.id/index.php/lentera_pendidikan/article/view/3809/3480

Muhaimin, \& Mujib, A. (1993). Pemikiran Pendidikan Islam. Bandung: Trigenda Karya.

Mulyasa. (2013). Standar Kompetensi dan Sertifikasi Guru (cetakan ke-7). Bandung: PT Remaja Rosdakarya.

Nurhamidah. (2018). Problematika kompetensi pedagogi guru terhadap karakteristik peserta didik. Jurnal Teori Dan Praksis Pembelajaran IPS, 03, 27-38.

Pianda, D. (2018). Kinerja guru: kompetensi guru, motivasi kerja dan kepemimpinan kepala sekolah. CV Jejak (Jejak Publisher).

Prastowo, A. (2017). Menyusun Rencana Pelaksanaan Pembelajaran (RPP) Tematik Terpadu. Kencana.

Rifma. (2016). Optimalisasi Pembinaan Kompetensi Pedagodik Guru: Dilengkapi Model Pembinaan Kompetensi Pedagogik Guru. Kencana.

Rofa'ah. (2016). Pentingnya Kompetensi Guru dalam Kegiatan Pembelajaran dalam Perspektif Islam. Deepublish.

Rukajat, A. (2018). Teknik Evaluasi Pembelajaran. Deepublish.

SDIT Ihsanul Amal. (n.d.). Retrieved 14 May 2019 from http://www.sditihsanulamal.sch.id/

Sembiring, M. G. (n.d.). Menjadi Guru Sejati. Galangpress Group.

Sugiyono. (2011). Metode Penelitian Kuantitatif Kualitatif dan $R \&$ \& D. Bandung: Alfabeta.

Surakhmad, W. (2009). Pendidikan nasional, strategi, dan tragedi. Penerbit Buku Kompas.

Syarifuddin. (2016). Observasi SD IT Ihsanul Amal.

Tim Penyusun, Sugono, D., Sugiyono, Maryani, Y., \& Taqdir Qodratillah, M. (2008). Kamus Bahasa Indonesia. Jakarta: Pusat Bahasa.

Yusuf, M. (2016). Metode Penelitian Kuantitatif, Kualitatif \& Penelitian Gabungan. Prenada Media.

Yutmini, S. (1992). Strategi Belajar Mengajar. Surakarta: FKIP UNS. 